This article was published in P. Peterson, E. Baker \& B. McGaw (Eds) International Encyclopedia of Education ( $3^{\text {rd }}$ edn.), Lo Bianco, Joseph (2010), Globalization, Universities and Medium of Instruction (pp. 201-208). Copyright @ 2010 Elsevier.

http://www.sciencedirect.com/science/article/pii/B9780080448947015062

\title{
Globalization, Universities and Medium of Instruction
}

\section{Joseph Lo Bianco}

\section{AD 1088: Ancient Globalization}

With the benefit of a millennium of hindsight, it appears ironical the University of Bologna came into being offering trade in secular expertise, including the ius gentium, the Roman law of peoples. These legal principles were useful in advancing the incipient right of nations, and defending nation-states against the predatory claims of their contemporary rivals, the transnational polities of Empire and Church. Bologna's self-narration (Czarniawska, 1997) today revolves around its special historic claim as Alma Mater Studiorum, the oldest continuously operating degree-awarding autonomous institution (Rüegg, 2003), not a college of scholars but a teaching institution independent of state power and religious authority (Huff, 2003: 179; Makdisi, 1981). Its origins demonstrate the truism that knowledge (its creation and transfer) and the skilled competence that knowledge generates are intimately tied to power. Although the social effects of such knowledge-power links are usually indirect and long term, they can be world changing.

The mother university emerged from scholarly effort to assemble and disseminate extranational authoritative knowledge. An ironical outcome was to promote national institutions and even nationality itself. Today, the name Bologna is a code word for procedures and structures in support of global higher education, returning it to its extranational origins. This is appropriate rather than ironical, since from its inception, organized higher learning has been international in content and aspiration. It is fitting too that the Constitutio Habita of 1158, Bologna's academic constitution (1155, according to Rüegg, 2003: 12), enshrines scholastic privilege, later venerated as the documentary origin of academic freedom (Watson, 2005: 373) in the struggle between the Pope and the Holy Roman Empire. This too became international, when on 18 September 1988, 430 university rectors signed the Magna Charta Universitatum, marking the 900th anniversary of the university's foundation.

All institutions engage in storytelling to solidify their constituents and define their distinctiveness (Gabriel, 2000; Boje, 2001). Bologna's self-narration tells a story of universalism, principles of institutional autonomy, and academic freedom a narrative that is today widely endorsed.

The training imparted at Bologna during the eleventh and twelfth centuries arose because new markets emerged (incipient nations and institutions) demanding skilled competence in law and legal rhetoric. Universities today, both Western and non-Western, are enmeshed in rapidly integrating markets for competence as they supply these markets with skills. Universities also reinforce the existence of these markets and their reliance on universities. These markets, then as now, transcend boundaries of nation and culture, though most are still grounded in national traditions and all are marked by stratifications of power and inequalities of wealth.

Bologna's quest for origins (D'Epiro and Pinkowish, 2001), despite serving nationalist claims, is largely confirmable (Rüegg, 2003). In AD 1088 (AD 1087, according to Huff, 2003) a certain Irnerius (and Pepo) commences teaching Emperor Justinian's sixth-century codification of Roman law, the 
Corpus luris Civilis, recently discovered at Pisa (Malagola, 1888). It is a confirmation of the irony that Irnerius' original academic activity was simply to gloss the ancient text, underscoring the indispensability of literate practices to all scholarly activity (Lo Bianco, 2004) while inadvertently adding value.

Lay students arrive in the city from many lands contracting to purchase this glossed knowledge. They organize themselves into collectivities, noncitizen guilds, or Learning Nations comprising Hungarians, Greeks, North Africans, Arabs, Franks, Germans, Iberians, etc. These became the locomotive of the educational economy, since students "had all the power ... and dominated the masters" (Kerr, 2001: 16, 145; Rüegg, 2003: 12). The Learning Nations serve many purposes: they enhance the purchasing power of students, impose lecturer diligence, require regular timetables, and provide rent control and other practical support.

In 1888, in the aftermath of Italy's national independence, a festival of studies was organised at Bologna to celebrate its eighth centennial (UniBo, 2008) as the mother of universities. The late nineteenth century, an era of internationalism marked by European imperial expansion, jars with the festival's theme of cooperative internationalism. However, while universities inevitably reflect their cultural and national setting, an internationalist impulse runs deep. Knowledge cannot easily be confined within bounded geopolitical spaces, and the technical skill and philosophical reflection that universities produce stimulates cross-border markets for their exchange. The marketplace for competence is international because technical efficiency and substantive reflection are endlessly mutable, applicable, and exchangeable.

Islam's earliest institutions of learning, madrasas, and higher education alike, were dispersed internationally, yet gathered around a shared textual tradition and modes of interpretation, all essentially forms of religious scholarship, but teaching and scholarship were also applied to science and law (Makdisi, 1981; Talabani, 1996; Daun and Arjmand, 2005). In diverse ways, universalism is found in all regions of the world, during all ages and across all civilizations (Hopkins, 2002), even in light of persistent arguments for the intellectual and moral roots of globalization, as distinct from economic and pragmatic ones, originating in European struggles (Headley, 2007). Today, the characteristic mode of higher education universalism applies an early 1800s' German conception of a research university adapted by American-inspired organizational and teaching models.

A shared medium of instruction (MOI) and standardized literacy are indispensable for the possibility of international education, even when the language concerned does not retain a home base in any nation.

Latin functioned in this way for some 14 centuries after Rome, making possible a Republic of Letters (McNeely and Wolverton, 2008); "almost unaffected by political and economic collapse" (Ostler, 2007: 18). This place-less Republic permitted elites to communicate and forge bonds of identity as "a community of scientists and scholars" (Ostler, 2007: 280). Today's Latin, on a historically unprecedented scale, is English, and perhaps because it does retain several home bases, English facilitates both the rise of international education and invests it with dilemmas, issues, and problems. It is important to note that it is not general spoken English that performs this facilitative function, but a range of identifiable registers of literate and persuasive academic English. To retain its privileged position, this kind of English is buttressed by a veritable industry of certification, assessment, and codification practices.

These practices are self-replicating and work to standardize, codify, and disseminate a teaching and written standard in scientific English discourse. Contemporary globalization is fueled by such communication practices making possible "the widening, deepening and speeding up of world wide interconnectedness" (Held et al., 1999: 2). Since the Lingua Mundi has not supplanted other 
languages of scholarship and science, these share the communicative load involved in research, publication, teaching, explanation, and dissemination. Some might ultimately pose a threat to the privileges and domination accorded to scientific English. The precedent of Latin is instructive; ancillary scholarly languages initially shared a minor, mostly spoken, role in academic communication with Latin, then expanded to share literate functions with Latin, and then under impulses of nationalism and pedagogical effectiveness rose to challenge and eventually displace Latin altogether. National vernaculars achieved this only after modeling their rhetorical and literary practices on Latin's example, and therefore today, in specialized vocabulary and modes of reasoning, perversely assure it some kind of permanence.

\section{AD 1999: Contemporary Globalization}

The education reform commonly known as the Bologna Declaration was signed on 19 June 1999 by 29 European countries aiming to establish a European Higher Education Area by 2010. Naming new semantic fields, codifying names, standardizing codes, and disseminating their use are all indicators of emergent fields. These processes permit calibration and standardization; comparable nomenclature accompanies degree simplification, permitting standard divisions between forms and levels of study, standard degree requirements, and a standard grading scale with common transcript. In its implementation, Bologna generates greater administrative coherence and procedural operations. The self-conscious aim is continent-wide comparability.

The expanding number of signatories, 45 at the time of writing, has meant that Bologna standardization has produced catalytic effects beyond its zones of application. Although ostensibly a move for administrative uniformity, Bologna will engender slow-acting but important long-term cultural consequences. One example is the European Credit Accumulation and Transfer System, leading to conversion from longer to shorter first degrees. More commonly designated bachelor graduates will facilitate masters-level expansion as the 3-year regime replaces most 5-year first degrees. Shorter duration first-degree standardization will accelerate study abroad, reduce first-degree government costs, and make master programs the major international study option.

Structural changes such as these fertilize the graduate education market, student behaviors, and study patterns, and make institutional dynamism more likely. In turn, these developments stimulate further adoption of English to attract nondomestic enrolments. More European countries are likely to offer price-based competition for international students in disciplines unconnected to local cultural or linguistic study, for example, English-medium business, technology, and science programs.

From their inception, universities have been the key global institution, far outlasting practically all other ancient institutions - functioning in a shared language, enrolling international students, engaging international academics, and disseminating knowledge beyond national borders. According to Altbach (2004), all universities today, other than Cairo's ancient Al-Azhar, originate from the European medieval university, with non-Western countries having European models "imposed on them by colonial masters. Even those countries not colonized by Western powers - such as Japan, Thailand, Ethiopia ... - adopted the Western academic model ... even where, as in China, well-established indigenous academic traditions already existed." (p. 4).

The 1999 Magna Charta Universitatum, now available in 47 languages, attracts increasing Asian, American, and African adherents, with signatories now totaling 579 (IPPT, 2008; UniBo, 2008) in 78 countries. It originated in the medieval recognition of rights to unhindered travel to study or teach; but fidelity to its principles of freedom and autonomy appears to be independent of setting and time.

Universalism in higher education therefore, has many sources and modalities: secular and religious, 
geographic and civilizational, technical and economic, and both imposed and voluntary. The modalities include cooperative charters of principle, competitive ranking of prestige, colonization and domination, and trade in commodified language and certified study (Tan and Rubdy, 2008).

\section{Globalization and Lingua Mundi}

A recent study by Cha and Ham (2008) documents historic patterns of foreign-language study. During $1875-99$, only $6 \%$ of secondary-school curricula worldwide nominated English as the first foreign language, increasing to $70 \%$ of primary and $80 \%$ of secondary curricula by 1990-2000. In Asia, English was represented in only $33 \%$ of primary curricula during 1945-69, growing to $83 \%$ in primary and $100 \%$ for secondary by 2005 . By 2006 , practically all instances in which foreign languages were employed to teach mainstream subject matter in Asian universities involved English. Recent growth in English is mostly independent of whether countries were British colonies or under American political influence, leading the authors to argue that English is no longer a foreign language, but rather a kind of foundational knowledge, or basic skill used for globalization. Supporting such claims are projections of English use as well as learning, particularly those made by Graddol (2006) who claims that English students and users might in a period of only two decades equal a third, or even half, the world's population. The diverse sources of demand for English produce innumerable local cultural and political meanings and effects. Global English defies temptations to depict its role in today's world according to a simple binary choice between imperial instrument and unproblematical asset. Concern often arises about English when it replaces teaching-through national languages, even in countries with long-standing national scientific-education traditions, for example, the Netherlands and Sweden. Recent debates about teaching in English had unpredictable effects, pushing policymakers to retreat from multilingual policies concerned about long-term vitality of Swedish as a result of exposure to globalization (Boyd, 2007: 175). This is also true in China, where obligatory English alongside Putonghua results in a tri-lingual and tri-literate burden on non-Han minority populations (Feng, 2007).

Human capital theorizations dominate education policies practically everywhere, and Englishdelivered instruction reflects and helps to strengthen a distinctive marketplace for competence, certification, and exchange. Internationally compared degrees, international universities, and student mobility are not exclusive to English, but it is the most consistent element in such arrangements. Representing English as a basic skill has the effect of reducing its foreignness and even of representing English as purely an instrument of communication, or a postidentity language (Lo Bianco, 2005). These labels and ways of talking about English are the discursive accompaniment to its material attractiveness as a commodity (Lo Bianco, 2007b; Tan and Rubdy, 2008).

The nature of this commodity is decreasingly Anglo-American and increasing number of Asian institutions position themselves as suppliers of general English and increasingly for specialized education through English. For some observers, a single global society (Cha and Ham, 2008) follows in the wake of English-mediated mass education with its standardized qualifications, increasingly portable form, and traded in an interlinked marketplace of skills. Perhaps, this is premature given the recency of domination by English as demonstrated in the Cha and Ham data; however, what is clear is the expanding number of extranational communities of communication founded in professional identities and facilitated by English-knowing bilingualism. These are evident in professional associations, professional conferences, and in the academic work and professional conversations that sustain these communities of communication. As these communities are elites within their own societies, this association of English as a medium is making possible horizontal linkages, that is, of elites across national boundaries, associates knowing English with social stratification and inequality.

As the medium of most international scientific literature and the most disseminated journals, both in print and electronic form, English clearly dominates the conversations of academic life. Access to its 
elevated registers is therefore, for individuals and institutions, a predictor of advantage, such as when competitive promotions rely on reputable publication in approved journals. English capability is increasingly associated with reward systems in higher education as reputation is a critical ingredient of systemic advancement. The reality is, however, that access to English, especially in developing countries, is distributed according to preexisting social, ethnic, and geographic divisions. Schooling, much less higher education, cannot adequately compensate for inherited advantages in access to the powerful written and spoken styles of English, which are often informally acquired in family and affinity networks that socialize privileged groups in cultural capital (Bourdieu, 2005). Education systems which favor English-delivered instruction, therefore compound existing inequalities for minority and poor populations who are precluded by prevailing social structures from acquiring prestigious forms of English.

The effort to reproduce and conform to the norms of academic life which prevail in Anglophone settings requires institutions and societies more generally to make adjustments that go beyond what occurs in universities alone, impacting deeply on social networks and relationships. Additionally, Altbach (2004) notes several ways in which English constitutes advantages for American and British authors and institutions, such as the cost of English-language databases, products and resources, direct experience in editing and housing scholarly journals, and procedural advantages in peer review and academic writing. Higher education institutions in developing countries find access to this array of advantage systems, through which critical information is negotiated and reputations forged, costprohibitive. Restrictions on ownership and usage, such as stringent copyright procedures, entrench existing hierarchies of control and quality and quantity of access.

However, there are other and more subtle cultural and ideological questions which arise, such as command of persuasive argument styles inherent in particular disciplines and their surrounding traditions of academic life (Lo Bianco, 2004). As the reasoning and rhetorical practices valued in the Anglophone tradition are associated with privilege and success within societies, indigenous versions of these practices can be displaced or challenged. While it is true that languages contain low ideology and relatively culture-free transactional styles, higher-order functions of language are hardly neutral. An important recent exploration of this is Wierzbicka's (2006) study of the persisting layers of culture in English. In this work, Wierzbicka finds semantic bias within the grammatical core and discursive styles of English contributing a significant installment in what is a long debate about how language and thought intersect. At the very least, this work serves to render problematic the often naive assumption that any language can be rapidly removed from its historic and contextual origins and shorn of traces of these, as occurs when English is considered a totally neutral tool of communication, an instrument without imprint of history and culture.

Formal university rankings represent a clear example of the language-prestige hierarchy. In the 2006 edition of the Shanghai Jiao Tong Index (SJTI), 19 of the world's 20 top-ranked universities were American or British and $66 \%$ of the top 100 were located in English-language settings. In his analysis of the SJTI, Marginson (2007a) argues that such rankings "... favour universities ... from English language nations because English is the language of research (non English language work is published less and cited less); and universities from the large US system as Americans tend to cite Americans" (p. 133).

Reflecting on this palpable advantage bias, Van Parijs (2007: 85) proposes a kind of native-speaker tax on Anglophones, payable to English learners to defray the costs of acquisition. Van Parijs calculates the subsidies involved, concluding that Chinese people would receive $€ 32.20$ per capita from the Anglo population; French speakers would be granted a $€ 24.24$ subsidy; and Danes would each receive $€ 23.76$. While Coulmas (2007) adopts a more accommodating stance he also acknowledges the extra burden imposed on non-native users of English but implies a possible future shift when he has an interlocutor in simulated conversation on scientific publishing conclude: "I 
registered for an intensive Chinese course yesterday" (p. 13).

\section{Gigantic Peripheries}

China, along with India, constitutes what Altbach (1998) has called gigantic peripheries to American and English-centered contemporary globalization. Since 1998, they remain gigantic but have moved close to the center of where knowledge and human capital economic power intersect. In very different ways, Chinese and Indian education systems reveal immense penetration by English.

In 2001, the Chinese Ministry of Education issued a stipulation that universities should provide $5-10 \%$ of undergraduate instruction in foreign languages (Pan, 2007), leading to considerable growth of English-Chinese bilingual teaching, and expanded the scope of English teaching at other levels (MinEd, 2001). An evaluation of these initiatives at East China University of Science and Technology in Shanghai found predictable problems of implementation and uneven readiness, but by 2006 bilingual education was flourishing; producing results superior to traditional English teaching (Pan, 2007: 212).

In such environments, English has two principal roles, as $\mathrm{MOI}$ and as object of instruction for English majors. Exploring this accelerating globalization in Chinese higher education, Chang (2006) also looks at adjustments to national English language policy.

Documenting a surge of use of English as MOI, Chang's study identifies the ripple caused into the basic university-training models, in revisions to the national curriculum and in textbook design and content. No fewer than six new training models had emerged: English major plus courses in other specialisms, English major plus an orientation toward other disciplines, English major plus a minor, a major plus English language, English language plus another foreign language, and dual degree - BA degree of English language and literature plus another BA degree.

It is unlikely that such an array of English-centered program designs and training models producing composite-type graduates, can be quarantined within English training or language departments in universities. Instead, it is more likely to cause organization adjustments throughout education, as what English training is, becomes meshed with basic academic preparation in a growing number of academic disciplines. English and Chinese will share the communicative load in some programs, such as collaborative degree programs discussed by Pan (2007) which are conducted in English with components of Chinese-language facilitation or support to enhance learning or to overcome predictable gaps. In other settings, such as Malaysia, which have a more established local history of English, there is growing use of English-only (Altbach, 2004; Kaur, 2004) or English-dominant programs.

The transnational status of institutions extends such intra-institutional changes brought about by English medium education. In a dramatic display of such developments, Science Magazine recently proclaimed that Chinese universities are now the top feeders for US doctoral programs. Reporting research showing that Tsinghua and Peking Universities "have topped the list of undergraduate schools whose graduates go on to earn a doctorate from an American university" (Mervis, 2008: 185) the story underscores the transnational dimension of contemporary higher education, the facilitative function of English, and the extent of mobility.

This integrated and global marketplace fosters trade in expertise with practically instantaneous exchange of information. The two prestigious Chinese institutions beat the University of California, Berkeley, to third place with Seoul University next. This cross-border transfer and burgeoning interdependence between US and Chinese higher education is accompanied by massive Chinese 
investment in high-scale research capability and increasing attraction to large numbers of in-bound students and academic staff in Chinese-language programs.

\section{Small Peripheries}

More asymmetrical is the relationship between globalized education products, processes, and certification, and small societies. Cambodia, with its history of multiple colonization and dependency, is an instructive and disturbing case. Exemplifying this is the case of the Royal University of Phnom Penh, founded on 13 January 1960 (Man and Luong Chan, 2002), incidentally a signatory to the Magna Charta Universitatum.

Cambodian language policy (Clayton, 2002) has been buffeted by colonization, immersion in global markets, and now by the influence of development assistance, often with linguistically tied programs. Influencing the communicative patterns of Cambodian society are strategic, cultural, ideological, and economic interests from outside, intertwined with domestic interests, and the choices that result from their interaction on questions of $\mathrm{MOI}$, minority-language rights and foreign-language preferences. All these points are in evidence in the recent history of one institution. Since its inception, the Royal University of Phnom Penh (originally Khmer Royal, then Phnom Penh University), taught mostly in French during the 1960s, underwent gradual Khmerization during the 1970s, conserving some use of French, but was closed due to political upheaval and violence between 1975 and 1978. During the 1980s, teaching was initially in Russian, later Vietnamese was added, and still later Khmer was included. In the late 1980s and early 1990s, first French then English were used alongside Khmer. From the early 2000s, teaching has been mainly in Khmer but with booming interest in English and residual use of French, often promoted as a condition of assistance (Man and Luong Chan, 2002; Clayton, 2006).

Despite the obvious disruptive effects of such changes, $\mathrm{MOI}$ policy is often taken to be a straightforward question of cost and efficiency. In this unproblematic depiction, a country or a single institution would simply calculate the costs of different language choices and opt for the cheapest and most feasible alternative. Informing the calculation of cost would be the availability of academic literature in the different language choices, the expense and feasibility of translation, and the availability and training costs of lecturers. Opposition to such efficiency-based reasoning is often represented as backward-looking nationalism or sentimentality. However, reducing $\mathrm{MOI}$ choices entirely to such a binary between cost and sentiment, or technical efficiency versus national-language ideologies, is crude, obscuring some very complex issues and problems, which extensive documentation of $\mathrm{MOI}$ policies reveal. Not least among these complicating factors are the potentially corrosive effects on the internal efficiency and vitality of national languages when they are excluded from high-level scientific discourses. Affecting people, rather than languages, are the ways in which $\mathrm{MOI}$ policies preferring foreign over local languages compound inequalities already faced by minority or disadvantaged groups. Neither of these arguments relates to sentiment, but to the practical effects, on people and on their languages, of favoring external or foreign languages over local ones.

In the light of this, it is not surprising that Tollefson and Tsui's (2004) survey of Asian experiences with $\mathrm{MOI}$ policy leads them to argue that there are always agendas involved in choosing a language of instruction, that these agendas align with particular interests, and are subject to change over time in response to shifting economic and political circumstances. We can see these shifts clearly in the case of Sri Lanka (Ceylon), Malaysia, and Singapore. In the postcolonial context of the mid-1950s, these countries all ejected English from their education systems for reasons of national reconstruction, nationalism, or local administrative consolidation; however, by the early 2000s all three had reinserted English both as an object of instruction and as MOI. In some cases, English has been restricted to teaching only some disciplines, especially science, mathematics, technology, and business studies, 
while in others it was used more widely (Lo Bianco, 2007a). In the mid-1950s, when English was evicted from education, there were protests in its defense, and today when English has been either fully or partially restored as a teaching as well as a taught language, there are varying levels of concern and agitation against its new status.

Kaur's (2004) examination of the Malaysian case isolates the contribution of higher education bifurcation to undermining Malaysia's previous ability to resist the incursions of English. Bifurcation refers to reforms permitting English-medium private universities to operate alongside Malay-medium public universities. These were the catalysts provoking a wider dismantling of the Malay-only $\mathrm{MOI}$ stance, eventually also in schools. Mon-lingual Malay-educated majority-population interests were made vulnerable by the marketplace advantages of English-knowing bilinguals, and in 2009, there continues to be vigorous debate about both the efficacy and desirability of using English to teach mainstream subjects and the ripple effects onto different ethnic and social groups. The public/private divide highlights how the asymmetrical acquisition of English compounds internal social stratification. A related situation typifies Sri Lanka (Lo Bianco, forthcoming) where language learning aligns with social opportunity, ethnic and racial backgrounds, geography, and social class.

Language planning in universities at a time of rapid and profound globalization can only be properly examined as choices situated within preexisting socio-political contexts, reflecting divergent interests and agendas as much as opening up new opportunities in emergent markets. Tollefson and Tsui (2004) rightly identify sociopolitical processes as key drivers of MOI choices, rather than unproblematical technical assessments of costs in delivery of content, or access to scientific literature. Even when cost and efficiency considerations predominate, debates about language policy cannot be credibly separated from inherited historical arrangements. Both the discourse, which accompanies $\mathrm{MOI}$ policy and the agendas various interests advance are underscored by Tsui's analysis of Hong Kong, in which the argues that $\mathrm{MOI}$ is:

... shaped by an interaction between political, social and economic forces...among these agendas, it is always the political agenda that takes priority. Other agendas...come to the fore only if they converge with the political agenda. Yet it is always these [other] agendas that will be used as public justification for policy making. (Tsui, 2004: 113)

\section{Conclusion}

Globalization transforms universities directly making research-based higher education, like finance services, a sensitive and exposed sector (Marginson, 2007b). Critical to national economic positioning, cultural production, and international communication, higher education achieves its capability through intense and endemic globalization. Knowledge-intensive sectors, industries and services, are aggregated around and within universities, making them large business corporations organizing the collection of knowledge and its dissemination in publishing, seminars, conferences, and applications of various kinds. These interactions bring to the surface an intense connection between English and technical knowledge and help make the language itself a commodity (Tan and Rubdy, 2008) traded in its distinctive marketplaces.

Although positioned in national states, knowledge economies are interlinked across national boundaries, and are organized by these global relations. Opportunities for mobility and employment opened up by English are not as well distributed and organized as is often supposed. English does not just mediate access to knowledge and skills, but is a substantial component of knowledge and skills. Languages and their associated literacies impose their own hierarchies and can compound endemic inequalities even when they offer new opportunities and prospects. The contemporary era of global education recalls its ancient precedents because it underscores the nonconfineability of 
knowledge and the internationalist impulse of the university. Education systems both celebrate and defend academic freedom and institutional autonomy and accommodate peripheries, whether gigantic or small, to norms that privilege arrangements set by the dominant centers of education. These patterns are linked to economic privilege and power, and align closely with the world's current language regime. While current language arrangements might not be assured or permanent, their entrenched power contains elements, which are self-fulfilling and which are deeply rooted in systems of reward, ranking, and comparison.

On the positive side, language-based globalization also promotes multiple channels of communication and increasingly uses technologies based on multiple literacies, combining digital, electronic, and visual with the print literacies of the past. These potentially expand the range of individuals and social groups able to participate in and benefit from higher education. No education will be immune from such epoch-making changes and even the most technical subjects and fields of research will have to deal with audiences, which are multicultural and highly mobile and communication technologies that threaten to disrupt the very basis of written literacy (Crossman, 2004). Scientific literate communication is as ancient as the institutions which rely on it, and its future forms appear to be as dynamic as their contemporary functions. As all such changes are located within endemically unequal arrangements, the ancient globalization of institutions sheds light on patterns that too often we imagine are unique in time.

\section{Bibliography}

Altbach, P. (1998). Gigantic peripheries: India and China in the world knowledge system. In Altbach, P. (ed.) Comparative Higher Education, pp 133-146. Greenwich, CT: Ablex.

Altbach, P. (2004). Globalization and the university. Tertiary Education and Management 10(1), 3-25. Boje, D. (2001). Narrative Methods for Organizational and Communication Research. London: Sage. Bourdieu, P. (2005). Language and Symbolic Power. Malden, MA: Polity Press.

Boyd, S. (2007). Communication and community. In Pauwels, A., Winter, J., and Lo Bianco, J. (eds.) Maintaining Minority Languages in Trans-National Contexts, pp 141-179. Basingstoke, UK: Palgrave.

Cha, Y.-K. and Ham, S.-H. (2008). The impact of English on the school curriculum. In Spolsky, B. and Hult, F. M. (eds.) Handbook of Educational Linguistics, pp 313-327. Malden, MA: Blackwell.

Chang, J. (2006). Globalization and English in Chinese higher education. World Englishes 25(3-4), 513-525.

Clayton, T. (2002). International languages in education in developing countries. In Lo Bianco, J. (ed.) Voices from Phnom Penh: Development and Language, pp 87-102. Language Australia: Melbourne.

Clayton, T. (2006). Language Choice in a Nation under Transition. New York: Springer.

Coulmas, F. (2007). English monolingualism in scientific communication and progress in science. In Carli, A. and Ammon, U. (eds.) Linguistic Inequality in Scientific Communication Today, pp 514. AlLA Review, Amsterdam: Benjamins.

Crossman, W. (2004). ViVo. Oakland, CA: Regent Press.

Czarniawska, B. (1997). Narrating the Organization. Chicago: University of Chicago Press.

Daun, H. and Arjmand, R. (2005). Islamic education. In Zajda, J. (ed.) International Handbook of Globalisation, Education and Policy Research, pp 377-388. Netherlands: Springer.

D’Epiro, P. and Pinkowish, M. D. (2001). Sprezzatura. New York: Anchor Books.

Feng, A. (ed.) (2007). Bilingual Education in China. Clevedon, UK: Multilingual Matters.

Gabriel, Y. (2000). Storytelling in Organizations. Oxford: Oxford University Press.

Graddol, D. (2006). English Next. London: The British Council.

Headley, J. (2007). The Europeanization of the World. Princeton: Princeton University Press.

Held, D., McGrew, A., Goldblatt, D., and Perraton, J. (1999). Global Transformations. Stanford: 
Stanford University Press.

Hopkins, A. G. (ed.) (2002). Globalization in World History. London: Pimlico.

Huff, T. (2003). The Rise of Early Modern Science. Cambridge: Cambridge University Press.

IPPT (2008). Institut Penyelidikan Pendidikan Tinggi Negara USM.

http://www.usm.my/ipptn/v2/documents/Globalupdates/Magna

\%20Charta\%20Universitatum-No\%2040.pdf (accessed October 2009).

Kaur, G. S. (2004). Medium of instruction policy in higher education in Malaysia: Nationalism versus internationalization. In Tollefson, J., Tsui, J., and Tsui, A. B. M. (eds.) Medium of Instruction Policies, pp 135-152. Erlbaum Publishers: Mahwah, NJ.

Kerr, C. (2001). The Uses of the University. Cambridge: Harvard University Press.

Lo Bianco, J. (2004). Widening access and literacy. In Osborne, M., Gallacher, M. J., and Crossnan, N. (eds.) Researching Widening Access, pp 65-76. London: Routledge.

Lo Bianco, J. (2005). No longer a (foreign) language: Rhetoric of English as post-identity language. Journal of Chinese Sociolinguistics 2(5), 17-41.

Lo Bianco, J. (2007a). Advantage plus identity: Singapore's MOI policy. In Vaish, V., Gopinathan, S., and Liu, Y. (eds.) Language, Capital, Culture, pp 5-22. Amsterdam: Sense Publishers.

Lo Bianco, J. (2007b). Protecting English in an Anglophone age. In Cummins, J. and Davison, C. (eds.) Handbook of English Language Teaching, pp 169-183. Norwell, PA: Springer.

Lo Bianco, J. (forthcoming). A friendly knife? English in the context of Sri Lankan language politics. In Farrell, L., Singh, U. N., and Giri, R. A. (eds.) English Language Education in South Asia. Cambridge University Press: India.

Makdisi, G. (1981). Rise of Colleges: Institutions of Learning in Islam and the West. Edinburgh: Edinburgh University Press.

Malagola, C. (1888). Statuti delle Università e dei Collegi dello Studio Bolognese. Bologna: Zanichelli.

Man, S. and Luong Chan, S. (2002). Building institutional capacity. In Lo Bianco, J. (ed.) Voices from Phnom Penh: Development and Language, pp 75-87. Melbourne: Language Australia.

Marginson, S. (2007a). Global university rankings. Journal of Higher Education Policy and Management 29(2), 131-142.

Marginson, S. (2007b). Prospects of Higher Education. Rotterdam: Sense Publishers.

McNeely, I. and Wolverton, L. (2008). Reinventing Knowledge. New York and London: W.W. Norton.

Mervis, J. (2008). US Graduate Training: Top PhD feeder schools are now Chinese. Science Magazine (July 11) 321(5886), 185.

MinEd (2001). Standard of English Courses for 9-Year Compulsory Education and General Senior High Schools. http://www.tefl-china. net/2003/ca13821.htm (accessed October 2009).

Ostler, N. (2007). Ad Infinitum, A Biography of Latin. London: Harper Press.

Pan, J. (2007). Facts and considerations about bilingual education in Chinese universities. In Feng, A. (ed.) Bilingual Education in China, pp 200-218. Clevedon, UK: Multilingual Matters.

Rüegg, W. (2003). Mythologies and historiogaphy of the beginnings. In De Ridder-Symoens, H. (ed.) A History of the University in Europe; Vol 1, Universities in the Middle Ages, pp 4-34. Cambridge: Cambridge University Press.

Talabani, A. (1996). Pedagogy, power, and discourse: Transformation of Islamic education. Comparative Education Review 40(1), 66-82.

Tan, P. K. W and Rubdy, R. (2008). Language as Commodity. London and New York: Continuum.

Tsui, A. B. M. (2004). MOI in Hong Kong. In Tollefson, J., Tsui, J., and Tsui, A. B. M. (eds.) Medium of Instruction Policies, pp 97-116. Mahwah, NJ: Erlbaum Publishers.

UniBo (2008). http://www.eng.unibo.it/PortaleEn/University/Our+History/default.htm. http://www.eng.unibo.it/PortaleEn/Students/

User+guide+to+Campus+Branches/User+Guide+to+Bologna/history.htm (accessed October 2009).

Van Parijs, P. (2007). Tackling the Anglophones' free ride. In Carli, A. and Ammon, U. (eds.) Linguistic Inequality in Scientific Communication Today, pp 72-87. AILA, Amsterdam: 
Benjamins.

Watson, P. (2005). Ideas. London: Weidenfeld and Nicolson. Wierzbicka, A. (2006). English: Meaning and Culture. Oxford: Oxford University Press.

\section{Relevant Website}

http://www2.unibo.it - Magna Charter of Universities, University of Bologna. 


\section{University Library}

\section{- M M I N E R VA A gateway to Melbourne's research publications}

Minerva Access is the Institutional Repository of The University of Melbourne

Author/s:

Bianco, JL

Title:

Globalization, universities and medium of instruction

Date:

2010-12-01

Citation:

Bianco, J. L. (2010). Globalization, universities and medium of instruction. Peterson, P (Ed.). Baker, E (Ed.). McGaw, B (Ed.). International Encyclopedia of Education, (3), pp.201-208. Elsevier.

Persistent Link:

http://hdl.handle.net/11343/112278 